\title{
How Competing Securitized Discourses over Land Appropriation Are Constructed: The Promotion of Solar Energy in the Israeli Desert
}

\author{
Itay Fischhendler, Dror Boymel \& Maxwell T Boykoff
}

Although solar farms are often favorably received by the public due to their contribution to clean energy, they are not conflict-free. In various contexts, this landintensive technology often competes with other land uses like agriculture, nature reserves, and army training. As a result of this competition, interest groups often seek political leverage in order to prioritize their spatial use. Framing their uses as existential is one possible way to capture the attention of decision-makers. Yet, this securitization process may create a framing contest whereby different actors use similar securitization language to promote different land uses. This study is the first attempt to trace how this framing contest of securitized discourses over land appropriation is constructed. It is based on the Israeli experience of promoting solar energy in the Negev Desert, an area conceived as available to solar development. Through an analysis of protocols of Israeli policy-makers' meetings between 2002 and 2011, the study documents the ways in which players adopt securitized language concerning various land uses such as energy, food, ecology, and traditional (national) security. The study found that the use of securitized framing varies between uses, forums, actors, and sectors. Yet competition between securities discourses remained uneven as, in the Israeli context, many players find it difficult to challenge the hegemonic role of traditional (national) security.

Keywords: security; conflicts; energy; solar farms; land use

\footnotetext{
Itay Fischhendler (Ph.D.) is a faculty member in the Department of Geography, Hebrew University of Jerusalem. Dror Boymel works for the Israeli Society for Nature Protection, Tel Aviv, Israel. Maxwell T. Boykoff (Ph.D.) is a Professor in the Center for Science, Technology, and Policy, University of Colorado, Boulder, CO, USA. Correspondence to: Itay Fischhendler, Department of Geography, Hebrew University of Jerusalem, Mount Scopus, Jerusalem 91905, Israel. Email: fishi@mscc.huji.ac.il
} 


\section{Introduction}

As a result of breakthroughs in solar technologies, punctuated by declining costs and ongoing carbon-based industry and climate challenges, many countries have stepped up adoption of solar energy policies in recent years (Garcia, Alzate, \& Barrera, 2012; Timilsina, Kurdgelashvili, \& Narbel, 2012). Solar energy adoption has not taken place merely as a sole alternative to fossil fuel energy sources; rather its promises and possibilities have been considered against the backdrop of other competing energy technologies and resources. This competition has ultimately tempered the deployment of solar technologies as a significant element of worldwide renewable electricity generation (Timilsina et al., 2012). One barrier to widespread adoption of much renewable energy-solar energy in particular-is their footprint on the landscape. Since both photovoltaic and concentrating solar power initiatives are land-intensive technologies often sited on open land, these technologies frequently compete with other energy sources and other potential land uses (Chiabrando, Fabrizio, \& Garnero, 2009). Indeed, land use is often mentioned as an important challenge regarding solar energy application (Oliver \& Jackson, 2001).

The extensive amount of land required for solar technologies encourages the allocation of agricultural land for energy uses (Chiabrando et al., 2009). This trade-off between land allocated for energy or for food production is well recognized and much discussed in the solar energy sector, since land demarcated for solar infrastructure inevitably competes with food production, (Dupraz et al., 2011). Solar energy can also compete with potential ecological uses as well, often disrupting natural habitats and fauna.

This competition and these trade-offs therefore motivate many involved in solar program promotions to work to gain the political support for their adoption in the public arena (Erge, Hoffmann, \& Kiefer, 2001; Hilgartner \& Bosk, 1988). Key actors in these spaces have therefore used communication strategies to engage with policymakers and citizens in order to recruit support for solar technology (Jacobsson \& Bergek, 2004). One such communicative strategy is the sociolinguistic concept of framing, of promises and possibilities, of solar technology adoption. Frames are thus used as strategic communicative tools for advocating new policies or altering existing policies (Bang, 2010; Kauffman, 2013). Recognized as critical for capturing the attention of policy-makers in the water (Gerlak, 2013), food (Dibden, Gibbs, \& Cocklin, 2013) and, of course, energy sectors (Bang, 2010), framing is vital to shaping public opinion, changing policies, and fostering collective action.

One type of frame that is gaining momentum in the environmental field is a "security" frame (Davies \& Selin, 2012; Deudney, 1991). Securitization implies that uses that were once debated in normal politics are now displayed as urgent and existential and demanding of exceptional measures (Buzan, Wæver, \& De Wilde, 1998). A common way to frame energy in order to capture policy-makers' attention more specifically is through the concept of "energy security." Presenting energy policy as urgent and existential makes it likely that the established energy policies can 
support a new type of policy change (Bang, 2010; Ciută, 2010) including the promotion of solar energy.

The ability of securitization to gather political support seems to encourage not only the energy sector to make use of the frame, but also other potential actors to frame their needs and resources in such a manner. Indeed security framing was already identified to capture the attention of policy-makers concerning various resources and uses like food security (Maxwell, 1996), climate security (Stripple, 2002, pp. 105-127; Risbey, 2008), ecological security (Inouye, 2008), and energy security (Ciută, 2010; Yergin, 2006). However, under scarcity conditions, the extraction of resources for one use may come at the expense of other uses. This proliferation of securitization language may create a "framing contest" in which many competing users utilize the same securitization frame in the race for resources and political support.

Hence, this study's aim is to trace if and how securitized "framing contests" among potential land uses is constructed. Examining if and how policy-makers navigate between many competing securitized discourses and frames can contribute to a better decision-making process, one that can account for implications of this framing mode. This study focuses on the process of land appropriation for solar energy in the Israeli Negev Desert, a setting that may represent a clash between different potential users and resources such as energy, climate, food, and the military. The study also examines the actors and sectors that tend to engage in such competition and the underlying triggers for this race among competing securities.

In the next section, the power of framing and discourse in agenda-setting will be explored further, followed by a review of securitization theory and the widening of the security framework to include environmental issues and natural resources.

\section{Framing and Discourse in Agenda-setting}

Framing is a well-known concept in studies concerning public opinion, political argumentation, and media representational practices (Chong \& Druckman, 2007; Gamson \& Modigliani, 1989; Lakoff, 2010). Through the use of "metaphors, catchphrases, visual images, moral appeals and other symbolic devices" (Gamson \& Modigliani, 1989), frames supply distinguishing ways to think about an issue and justification for the ways of addressing it (Lakoff, 2010). Given that frames can lead to collective action and the mobilization of political power, framing is often used in relation to environmental issues and natural resources (Lakoff, 2010). When it comes to these issues, frames are often used as an agenda-setting device to capture the attention of policy-makers for environmental issues (Cox, 2006, 2010; Dearing \& Rogers, 1996).

Although frames offer a preconceived way of thinking about an issue, they do not tell the entire story. The concept of "discourse" offers a more complex way of understanding the communication of an issue, and hence, its likelihood to be placed on decision-makers' agendas (Anderson, 1997; Carvalho \& Peterson, 2012). If the concept of framing relates to the way one understands a word or issue, a discourse 
can be understood as the shared way to apprehend the world (Dryzek, 1997). Maarten Hajer has defined "discourse" as:

an ensemble of ideas, concepts, and categories through which meaning is given to phenomena. Discourses frame certain problems; that is to say, they distinguish some aspects of a situation rather than others...discourses provide the tools with which problems are constructed ... [and they] dominate the way a society conceptualizes the world. (1993, pp. 45-46).

Discourses are embedded in language, and as such, are held together by pieces of information communicated (often by various frames) by certain "community members" as coherent stories (Dryzek, 1997). Further, both discursive and material elements comprise the politics of discourses over land appropriation. Discourses are tethered to material realities, perspectives, and social practices (Hall, 1997) as we examine through the case of solar energy promotion in the Israeli Negev Desert.

\section{Securitization as a Framing Mechanism in Sustainable Development Discourses}

The phenomenon of securitization has been analyzed by several researchers collectively known as the Copenhagen School (Buzan \& Wæver, 1997; Floyd, 2007). They perceive the securitization of an issue as a mode of framing whereby "regular" issues are lifted beyond the level of normal politics (Buzan et al., 1998) into the realm of "panic politics" (Wæver, 1995). The process of securitization now encompasses civil issues while still displaying them in an urgent and survivalist manner (Buzan et al., 1998). Although natural resources were often used interchangeably with the notion of securitization (e.g. Maxwell, 1996; Yergin, 2006), it was only in the 1960s and 1970s that natural resources became the locus of the securitization process. During these two decades, the importance of economic security arose through concerns around US dependence on foreign oil, increasing trade deficits, competition with other producers in the global market, and other economic components (Buzan, 1997). These concerns, coupled with the 1970s oil crisis, gave birth to the developing concept of energy security, which was later used to convey the importance of energy to regional stability and its instrumental use in conflict (Ciută, 2010; Yergin, 2006).

In the 1990s, a proliferation of literature was produced concerning environmental security (Deudney, 1991; Homer-Dixon, 1991). While in many cases environmental security was still situated on the nexus between scarce natural resources and national security agendas (Levy, 1995), other cases stressed the implications of environmental scarcity to communities and its impact on their well-being (United Nations, 1994). Food security is another example of a resource in which the meaning of security expanded to include civic elements. While the narrowest definition concerns the availability of minimum amounts of food at the global, national, communal, or household level, during the late 1980s its meaning expanded to include concerns about entitlements to food products as a component of affordable pricing (Maxwell, 1996). 
Two new and related concepts are climate security and ecological security, which emerged as a reaction to the understanding that human activity leads to global change (Floyd, 2012). For climate security, the intention is often to secure a stable climate or maintain a rate of change below levels deemed hazardous for human and ecological systems (Stripple, 2002, pp. 105-127). Often, the fear is that unless there is climate security, the provision of food and water supplies will be at risk. In contrast to energy security, the impetus for providing ecological security by protecting biodiversity is often the intrinsic value of species richness rather than their importance for the state or mankind (Inouye, 2008).

\section{Competing Security Discourses and Potential Implications}

The notion of scarce resources and its implications is well researched in the study of environmental discourse (Dryzek, 1997). Indeed, during the 1970s the neo-Malthusian approach was repeatedly voiced as a response to resources crises, such as the oil embargo and rising food prices. The scarcity of resources and its ramifications in the last two decades have shifted the current emphasis from the provision of each individual resource to the inextricable interdependence between these resources, producing most ostensibly the climate-water-food nexus (Hanjra \& Qureshi, 2010). Now energy is also attached to this nexus since biofuels, major consumers of water and agricultural land input, are expanding (Dupraz et al., 2011). The inextricable interdependence between resources implies that the endowment of resources for one use must take into account the long-term ramifications on other uses competing for the same resources. The notion of "competing uses" or "alternative uses" is well recognized in environmental economics. In such instances, users compete over the endowment of the same resources, such as land or sea (Timmons, 1956). When competition erupts it is important to understand how the relevant uses were displayed and "marketed" to the public and to decision-makers possibly by a securitization framing. Under such framing, uses considered to be low politics are linked with the high politics of national survival, such as peace and war. This embedding of a lower priority use in a wider political and existential setting, via securitization of the discourse, is expected to provide political leverage to interest groups over other competing uses.

Once one use is securitized, other competing uses may use the same framing approach. This may result in competing security discourses between actors. Hence, competing securities imply that varying uses and players compete to secure adequate and stable quantities and qualities of one particular resource at the expense of other securities. These uses may compete over resources like land, water, or labor while using the same securitization framing. For example, it has been observed that competition and trade-offs exist between climate-related goals (often framed as climate security) and food security (Yang, Zhou, \& Liu, 2009) in policies that promote biofuels.

Securities may not always compete against one another but rather complement one another. One example is the need to provide water security for the purpose of attaining food security and national security (Zeitoun, 2011). It is logical that different actors 
may form collectives for the purpose of promoting their interests, while those interests are intersected. This perspective is advanced through the Advocacy Coalition Framework (Sabatier, 2011). Therefore, coalitions that include several securitized uses may be generated when the storylines of actors that promote different securities complement one another. For instance, promoters of climate security and energy security may share their beliefs about renewable energy production as a way to cooperate on climate and energy problems (Brown \& Huntington, 2008).

Competing securities may be aggravated and legitimized by both physical and social factors. While natural catastrophes are often presented as a physical element that may legitimize the use of securitization framing (Pelling \& Dill, 2005), the need of players to prioritize their frame over other competing uses and policies is an example for social factors. Indeed, perceiving securitization as a social construct has led some scholars to argue that the securitization of the environment is just a rhetorical device aimed at drumming up greater support (Levy, 1995), termed by Deudney (1990) as "rhetorical attention-getting."

The implications of this competition is especially challenging whenever it comes to securitization as a framing mode. Securitization as a profile raiser was already noted to have negative implications. Securitization may lead to the taking of extreme measures based on "a zero-sum rationality" while "cooperative efforts required by environmental problems" are undermined (Trombetta, 2008, p. 586). Balzacq (2005) warns that this can lead to a freezing of policy deliberations, more broadly, as every issue can be turned into a security concern through language, the ability to determine which issues are real security concerns becomes diminished.

If discourses are identified as the shared way in which an issue is understood (Dryzek, 1997), then further examination into the construction of security discourse and framing may reveal the logic created from the shaping of an issue as an existential threat. As such, negotiations over language and phrasing highlight important interactions between discourse and practices. In articulating the important ways in which material realities shape discourses through time and space, geographer David Harvey has commented, "Struggles over representation are as fundamental to the activities of place construction as bricks and mortar" (1990, p. 422). Through this "historical dialectical materialist" approach, the ways in which resource-based securitization issues are framed strongly influence considerations of possible responses, as well as policy priorities.

The next section discusses the promotion of solar energy in the Israeli Negev Desert for the purpose of demonstrating if and how competing security discourses are constructed; by whom, for what purpose, and under what conditions.

\section{The Promotion of Solar Energy in the Israeli Negev}

Why build solar farms?

The motivation to diversify Israeli energy resources can be traced back to the 1973 Arab energy embargo where the Organization of the Petroleum Exporting Countries 
(OPEC) members raised oil prices sharply and cut production amounts. This was followed by a complete boycott of oil distribution to pro-Israel countries. Despite a "warming" between certain Arab countries and Israel, the overall Israeli-Arab conflict has not permitted Israel to rely on Arab energy resources (Bahgat, 2008). The geopolitical setting of Israel, which can be described as inundated with varying levels of conflict with all its neighbors, induces Israel to seek energy resources independence (Bahgat, 2008). However, the motivations to develop solar energy are numerous and not strictly based on the geopolitical conflict.

The Israeli electricity economy can be characterized by low power reserves. In 2002, for example, the electricity generation reserve during peak consumption was only $0.2 \%$, while the yearly average in the last decade was $6.3 \%$ (Israel Electric Corp., 2012). This is a consequence of the high level of growth in electricity consumptionan average of $3.4 \%$ each year in the last decade-which is not totally supported by a significant enlargement in generation ability reserve.

In addition to a lack of energy resources, Israel functions as an "energy island" due to its isolated energy system which is not connected to neighboring countries' electricity grids. Combined with low power reserves and a high dependence on foreign energy resources, the significance of local energy resources development, such as solar energy, is critical (Shaffer, 2011). Finally, another motivation for the promotion of solar energy stems from Israel's declaration of its intent to reduce its greenhouse gas emissions by $20 \%$ by the year 2020 (Ministry of Environmental Protection, 2011).

\section{From needs to solar energy policy}

Given the geo-strategic setting and the potential for solar energy, policy is typically made by the upper echelons of the government. The government itself takes the lead in making fundamental decisions in conjunction with the Ministry of Energy and Water Resources, which are implemented by the Electricity Authority. The prioritization of electricity generation using solar energy can be traced to government Decision 2664 of 4 November 2002, which stated that $2 \%$ of all electricity produced by 2007 will be from renewable sources, increasing to 5\% by 2016 (Government of Israel, 2002). Following the 2002 government decision to promote solar energy, the Planning Administration in the Ministry of the Interior appointed a specialized committee charged with finding suitable sites for the development of solar power plants in the Negev Desert.

As a response to Decision 2664, in 2007 the government decided to build two large power plants near Kibbutz Ashalim in the Negev Desert, while also assigning the Ministry of National Infrastructure the task of promoting renewable energy projects as national infrastructure projects (Government of Israel, 2007). In 2008, the government decided to give tax benefits for photovoltaic facilities (Government of Israel, 2008). A year later, it updated its renewable energy targets, which were initially set in 2002, to $5 \%$ and $10 \%$ of renewable energy by 2014 and 2020 (Government of Israel, 2009). 
Both solar energy quotas and subsidized tariffs have been used to manage solar energy production in recent years. Following the setting of tariffs and quotas, many initiatives have been submitted to various Israeli planning and construction bodies by the private sector. In parallel, the National Master Plan 10d10 for photovoltaic facilities was approved in order to simplify the procedures for rooftop solar initiatives and medium facilities on land. As a consequence, around 70 facilities of this kind are currently being promoted.

Most of the medium-size facilities and all of the large ones are to be situated in the Israeli Negev Desert, which covers approximately $60 \%$ of Israeli territory and populates only $14.3 \%$ of the population (Central Bureau of Statistics, 2012). Given the low population density combined with the physical conditions that the Negev Desert provides it has been argued that the Negev is highly suitable for solar energy development.

\section{The potential for competing security discourses over land}

In reality, the Negev Desert accommodates many uses that require extensive tracks of lands. The main user is the Israel Defense Forces (IDF), which uses about $55 \%$ of the Negev area mostly for training (The State Comptroller, 2011). In conjunction with training activities, many bases are scattered throughout the desert, providing logistic, radio and intelligence facilities, air force bases, and experimental areas for weapons. Moreover, the Negev Desert is also one of the most important areas of nature reserves and national parks in Israel. It provides the most extensive expanse of land in which natural habitats are significantly separated from settlements and roads, and provides open space continuity (Deshe Institute, 2012). The importance of open spaces and nature values is also supported by National Master Plan 35, which often restricts development in these areas. Consequently, $24 \%$ of the Negev is defined as nature reserves and national parks, which places even stricter limitations on development (Israel Nature and Parks Authority, 2012). Yet given the army's need for land, 66\% of the nature reserves are used by the military (Deshe Institute, 2012).

A final land use in the Negev Desert is agriculture, which extends over $8 \%$ of the desert, rendering the Negev agricultural land quantitatively significant for Israel's agricultural economy. Although many perceive the Negev as inappropriate for agriculture, the Ministry of Agriculture and Rural Development sees the Negev Desert as the "granary of fresh products" of Israel, while the rural settlements are viewed as the guardians of national lands, borders, and, by extension, national security (Ministry of Agriculture \& Rural Development, 2007).

\section{Methods}

\section{Research database}

On 4 November 2002, the Israeli Government began to actively promote renewable energy (Government of Israel, 2002). Since then, discussions on solar initiatives have 
been on the table in many different arenas and on many levels of decision-making. Some of these arena discussions are backed up by formal protocols of Parliamentary Committees, the National Planning and Construction Council and its subcommittees, the Southern Regional Committee for Planning and Construction and its subcommittees, and the Committee for Examined Alternatives for Locating Solar Power Plants (referred to as the "Technical Committee").

For the purpose of this study, all of the protocols of the meetings from the beginning of 2002 and until the end of 2011 were examined while all meetings that dealt with solar energy were collected. Table 1 summarizes the database, which includes a total of 81 relevant protocols.

Analyzing different protocols from different arenas is influenced by Hilgartner and Bosk's "Public Arenas Model" that has already showed the importance of different public venues on both the evolution of social problems and the actors who make claims about them (Hilgartner \& Bosk, 1988, p. 58).

\section{Securitized statements}

In each protocol, statements which framed one of the five securitized uses (climate, energy, ecology, food, or traditional national security) for land were sought. A statement was considered securitized if the land uses were displayed as security issues while using a rhetorical structure based on dramatization and presentation of the issue as a supreme priority. This was based on the Copenhagen School's criterion that securitization requires the creation of a security plot often by the use of words that evoke a sense of immediate physical harm. Hence, during the reading of the protocols, words and phrases such as "danger," "critical," "threat," "severe damage," or "existential need" were identified as keywords that signal securitization. Each statement framed by an actor as a security use was considered one observation and was thereafter called a "securitized statement." This implies that the number of securitized statements that one protocol can include may range from none to several. In 41 protocols, out of the total 81, at least one securitized statement was found. In total, 182 securitized statements were found (see Table 1).

Another criterion used to identify whether statements are securitized is the use of a referent object. A referent object is based on the Copenhagen School's unit for

Table 1. Research database.

\begin{tabular}{lccc}
\hline Forum & $\begin{array}{c}\text { No. of } \\
\text { protocols }\end{array}$ & $\begin{array}{c}\text { No. of protocols } \\
\text { with securitized } \\
\text { statements }\end{array}$ & $\begin{array}{c}\text { No. of securitized } \\
\text { statements }\end{array}$ \\
\hline Parliamentary & 13 & 12 & 65 \\
$\quad$ Committees & 32 & 16 & 84 \\
National Council & 32 & 10 & 22 \\
Regional Committee & 4 & 3 & 11 \\
Technical Committee & 81 & 41 & 182 \\
Total & & & \\
\hline
\end{tabular}


security analysis: the "things that are seen to be existentially threatened" and have "a legitimate claim to survival" (Buzan et al., 1998, p. 36). Referent objects were therefore categorized as broadly as possible for each potential securitized use: The main threats to climate security are the economy, humanity, and life support systems. The main threats to energy security are affordability, independency, public health, and reliability. The main threats to ecological security are biodiversity and life support systems. The main threats to food security are affordability and reliability. Finally, the main threats to national security are confidentiality, flight safety, military training, and operational capability.

The securitized statements were also divided into explicit and implicit securitization groups. The explicit securitization group was composed of statements in which the actor used specific words from the security sphere like "threat," "danger," "live," and so on. The implicit group included statements in which the actor emphasized the importance of the use compared to other uses but without using existential vocabulary. The sectors associated with the actor who made the securitized statement were also recorded. These include infrastructure, land-use planning, agriculture, environment, military, monetary, and others. Similarly, the actors who made the securitized statement were categorized as businesses, politicians, public servants, or NGOs. Finally, the arenas in which the securitized statements were deliberated (Parliament, National Council, Regional Committee, or Technical Committee) were recorded, assuming that the arena represents different degrees of politicization that may affect the intensity of competition between securitized discourses.

\section{Competing security indexes}

In addition to the analysis of the securitized statement as an individual research unit, the study also developed two competing security indexes with the aim of reflecting the intensity of competition between securitized uses per protocol.

The indexes are:

- Competition index number 1 . The ratio between the number of different securitized uses which were raised in each protocol and the maximum number of potential securitized uses in the relevant protocol. The maximum number of potential securitized uses is five and refers to the five different uses in this study. Higher ratios thus indicate higher competition. For example, in a protocol that contains references to energy security, traditional security, and food security, the ratio will be $3 / 5$, as only three uses are expressed out of five potential uses. However, since some protocols are short and have less than five securitized statements, the denominator is the number of statements. For example, in a protocol, which contains four securitized statements (two around energy security and two around traditional security), the ratio is $2 / 4$.

- Competition index number 2. The ratio between the second most mentioned securitized use and the most mentioned securitized use in the protocol. For example, a protocol in which traditional security is mentioned only three 
times, while energy security is mentioned four times would result in a ratio of $3 / 4$ (0.75). Higher ratios for this index also indicate higher competition. Since in many protocols, only two different securitized uses are raised, this index reflects the competition rate between these two competing uses.

\section{Results}

Who securitizes the discourse and how?

Table 2 presents the results of the distribution of the securitized statements by uses. It also presents the distribution of each securitized use by the arena in which it was displayed. Finally, the last column presents the ratio between explicit securitized statements and the total securitized statements for each use. For instance, out of the total securitized statements energy served as the securitized use for land appropriation in $40.1 \%$ and $58.9 \%$ of all the energy security statements made in the parliamentary forum. The ratio between explicit and the total securitized statements of energy was 0.64 .

It is clear from Table 2 that energy and traditional uses are the main uses often discussed in a securitized manner in Parliamentary Committees and in the National Council and often in an explicit securitized language. Ecology and food securities are the less voiced securities and are rarely discussed in an explicit securitization language. Alternative rationales to securitization are provided for these two uses. While for the former land use, the rationale for ecological preservation is often the legal obligation of Israel to comply with international agreements around nature protection; for the latter use the land should remain appropriate for agriculture, as agriculture provides positive externalities like maintaining the rural landscape and values. The same legal framing for ecological preservation seems to be also common in justifying appropriating land to solar farms as Israeli was often presented to be part of the global community that is legally committed to combat climate change.

Table 3 provides examples for quotations provided by different stakeholders describing various land uses in a securitized manner. This suggests that a variety of

Table 2. Distribution of securitized statements by uses, arena.

\begin{tabular}{|c|c|c|c|c|c|c|}
\hline \multirow[b]{2}{*}{$\begin{array}{l}\text { Securitized } \\
\text { use }\end{array}$} & \multirow[b]{2}{*}{$\begin{array}{c}\% \text { of } \\
\text { securitized } \\
\text { use out of } \\
\text { total } \\
\text { statements }\end{array}$} & \multicolumn{4}{|c|}{$\%$ of securitized issues, by arena } & \multirow[b]{2}{*}{$\begin{array}{c}\text { Ratio between } \\
\text { explicit and } \\
\text { total } \\
\text { securitized } \\
\text { statements }\end{array}$} \\
\hline & & Parliamentary & $\begin{array}{l}\text { National } \\
\text { Planning } \\
\text { Council }\end{array}$ & $\begin{array}{l}\text { Regional } \\
\text { Planning } \\
\text { Committees }\end{array}$ & $\begin{array}{l}\text { Technical } \\
\text { Committee }\end{array}$ & \\
\hline Climate & 8.8 & 87.5 & 6.3 & 6.3 & 0 & 0.38 \\
\hline Energy & 40.1 & 58.9 & 35.6 & 4.1 & 1.4 & 0.64 \\
\hline Ecology & 7.7 & 7.1 & 71.4 & 14.3 & 7.1 & 0.14 \\
\hline Food & 6 & 27.3 & 54.5 & 18.2 & 0 & 0.09 \\
\hline Traditional & 37.4 & 5.9 & 60.3 & 20.6 & 13.2 & 0.57 \\
\hline
\end{tabular}


Table 3. Examples for quotations around securitized uses.

\begin{tabular}{|c|c|c|}
\hline $\begin{array}{l}\text { Securitized } \\
\text { use }\end{array}$ & Quotation & Spokesman \\
\hline Energy & $\begin{array}{l}\text { "Energy dependency and a decentralized energy } \\
\text { (via solar farms) system is essential to our } \\
\text { security" }\end{array}$ & $\begin{array}{l}\text { Einnat Vilaf, Parliament } \\
\text { Member }\end{array}$ \\
\hline Food & $\begin{array}{l}\text { "If tomorrow morning Hatzav [settlement) } \\
\text { doesn't have [agricultural) lands, you will not eat } \\
\text { Cauliflower and Lettuce" }\end{array}$ & $\begin{array}{l}\text { Shlomi Shamai, Deputy Head of } \\
\text { Regional council of Beer Tuvia }\end{array}$ \\
\hline Climate & $\begin{array}{l}\text { "In the last assessment report [of the IPCe], the } \\
\text { third assessment, it was very dramatic in the } \\
\text { aspect of the threat over the future living in the } \\
\text { earth" }\end{array}$ & $\begin{array}{l}\text { Dov Khenin, Parliament } \\
\text { Member }\end{array}$ \\
\hline Energy & "Energy is the essence of life of the country" & $\begin{array}{l}\text { Joseph Paritzky, Minister of } \\
\text { National Infrastructure }\end{array}$ \\
\hline Ecology & $\begin{array}{l}\text { "for the man who benefits from the gifts of } \\
\text { nature, from Yoav Sagie, Society for the } \\
\text { advantages from the system services of nature, } \\
\text { which without them Protection of Nature in Israel } \\
\text { we have no life and have no existence" }\end{array}$ & $\begin{array}{l}\text { Yoav Sagie, Society for the } \\
\text { Protection of Nature in Israel }\end{array}$ \\
\hline
\end{tabular}

linguistic tools are deployed to deliver a sense of urgency and existentialism including voicing the looming threats to our life if land uses like maintaining agriculture or appropriating land for solar farms will be jeopardized.

As explained in the methods section, the study distinguished between sectors and actors. Table 4 below summarizes the results of the sectors and the actors that made the securitized statements on each issue. It indicates a sectorial approach under which different sectors and their actors promote their own interest in a securitized manner. For example, since energy security has profound infrastructure implications it was often raised by the infrastructure ministry and voiced by its public servants. Similarly, the environmental ministry raised ecological security, with NGOs voicing these concerns. Finally, politicians have an important role in voicing energy security concerns while public servants are the most vocal concerning the other uses.

\section{Threats over referent objects}

In Figure 1, five pie charts are displayed, one for each securitized use. The figure shows the division between the main threats that arose in securitized statements of each use. The category of "unclear" relates to all the securitized statements where the threats were nonexistent or unidentifiable. The pie charts clearly demonstrate that in many cases the threat behind the use discussed could not be identified, especially when discussing climate, food, and, to some extent, also energy. For most uses, it is clear that there is one dominant threat. For ecology, this is biodiversity; for traditional security, it is military training; and for food, it is reliability of food supply. Energy is the exception, as the threats discussed are diverse. 
Table 4. Distribution of the securitized uses between sectors and actors.

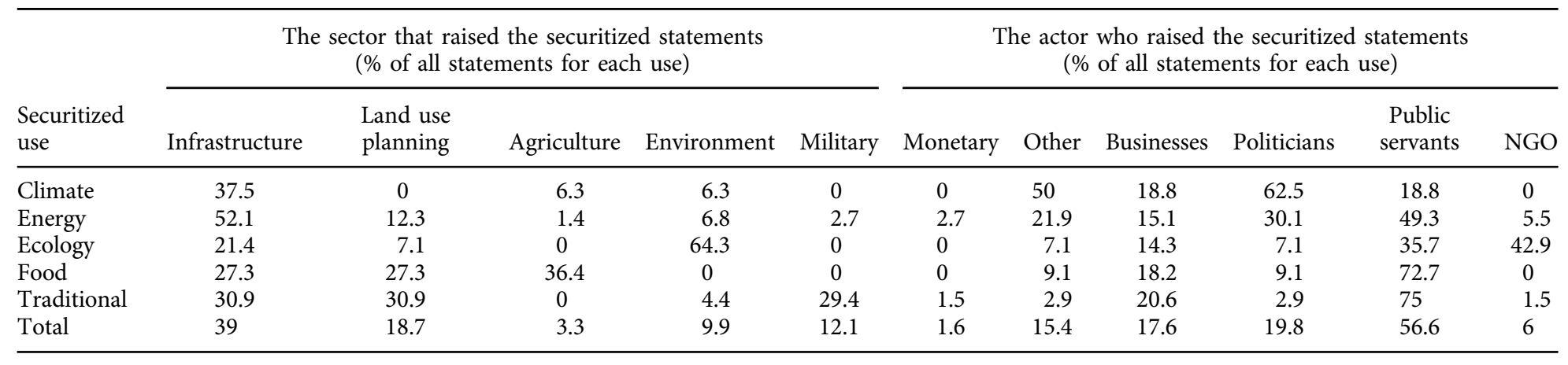




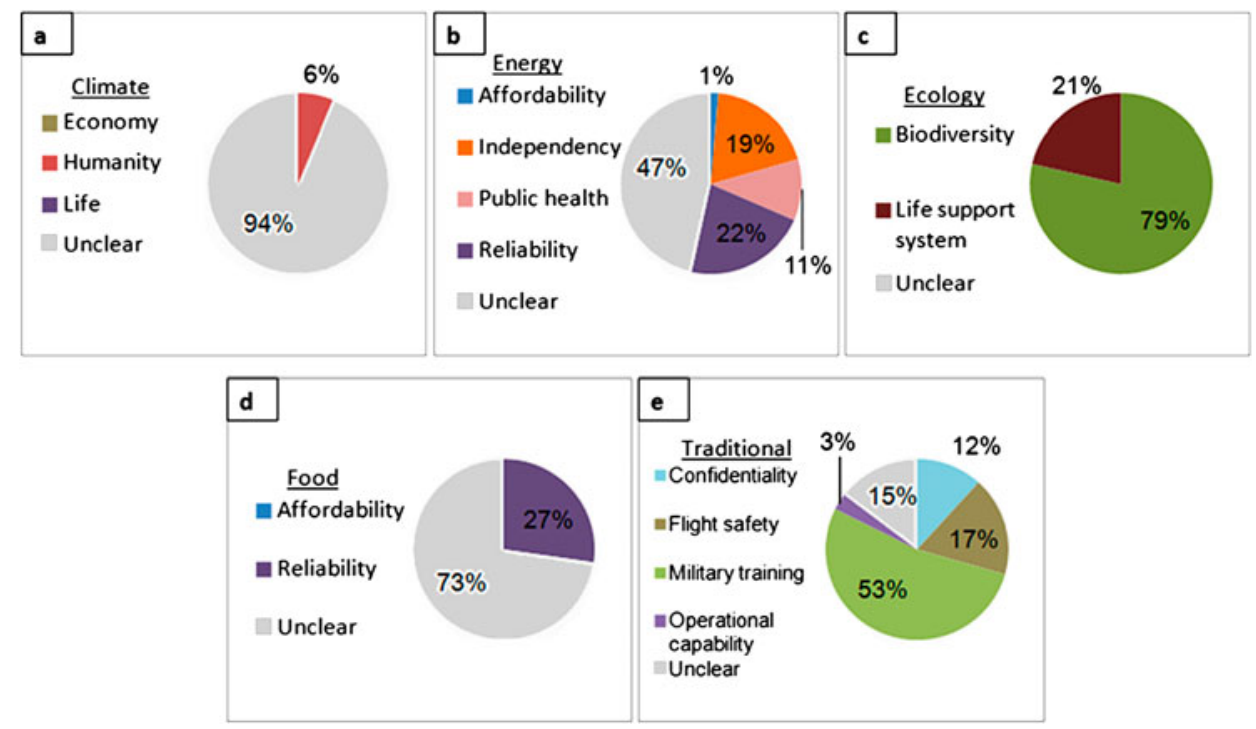

Figure 1. What is at risk for each of the securitized uses.

The distribution of competition indexes by arenas

Figure 2 presents the competing security indexes for each of the 41 protocols that contain at least one securitized statement. The protocols that were analyzed differ from one another in the intensity of their competition indexes. The figure displays these results by arena for the two competition indexes, suggesting that the competition indexes vary across time and between arenas. It is clear that for the Technical Committee, the competition level was lower than for the Parliamentary Committees and the National Council. Although the competition indexes for the regional committees vary over time, they are clearly lower than for the Parliamentary Committees and the National Council. In fact the average index for competition index 2 for Parliamentary Committees and for the National Planning Council is 0.39, while for the Regional Planning Committees and for the Technical Committee it is 0.17 and 0.05 , respectively. Although the two indexes often displayed similar patterns, the Parliamentarian Committees showed higher rates in index no. 1.

\section{Discussion}

As van Dijk (1988) and others have pointed out, discourses themselves must be carefully considered in context (e.g. Hansen, 1991). Our case study analysis of solar energy promotions in the Negev setting confirms our expectation that the inextricable interdependence between resources and land scarcity encourages many players to frame their potential uses as existential and urgent. This creates competition between securities once a new spatial use (like solar farms) is introduced after the resource (in our case land) has already been appropriated. 

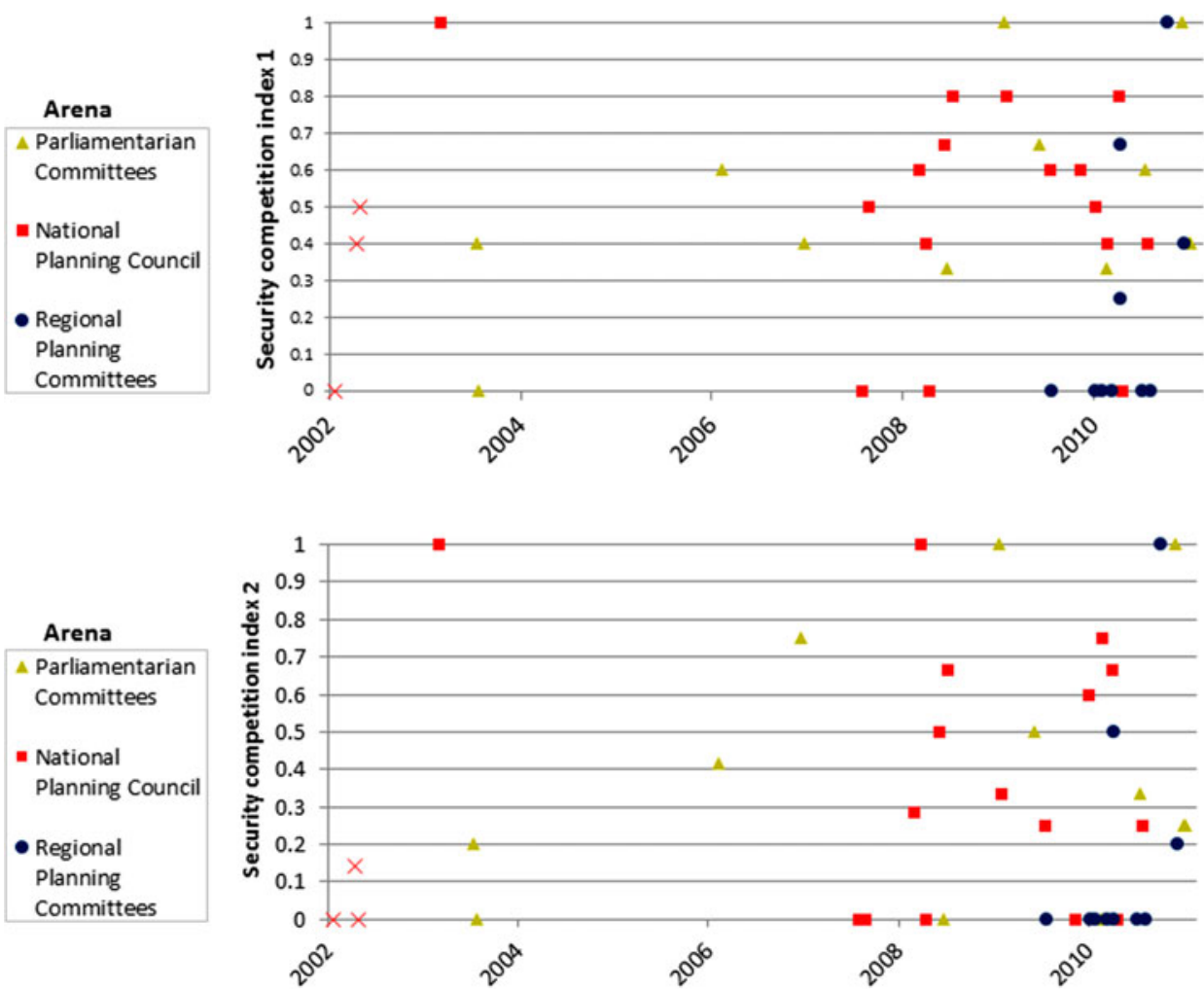

Figure 2. Security competition indexes per protocol by time and by arena.

Yet, how this physical trigger for securitizations plays out varies as a function of societal factors including the issues, arenas, actors, and the sectors voicing such framing mode. For example, the results showed that public servants and the infrastructure sector more frequently raise the "energy security" discourse while "ecological security" is more frequently raised by NGOs and the environmental sector. The results also indicate that not all securities are equally voiced, as energy and traditional (national) securities were most common while ecological and food securities were nearly nonexistent. Moreover, the results indicate that actors choose different ways to securitize an issue. Some used explicit language to securitize while others chose implicit language to convey a securitized message. The use of explicit or implicit securitization and the intensity of the competition between securities is a function of arenas and uses. The higher the degree of politicization of the arena the more the competition between securities is intensified and the more explicit the securitization language is.

As explained earlier, the Copenhagen School lists several essential conditions for a discourse to be qualified as "securitization." One condition is to point to a clear threat. However the results showed that in many statements the actor refrained from 
identifying clear threats to a referent object (Figure 1). This lack of a referent object under threat is common in discussions pertaining to climate and food security and, to some degree, energy security. This suggests that the framing of securitization was triggered by marketing reasons with the aim of placing the topic on the agenda rather than by a genuine belief for the effect of physical factors such as land scarcity. This suggests that there are two types of securitization pertaining to natural resources. One is strategic securitization that is motivated by the assumption that scarcity of some uses can lead to conflicts, economic decline, and poverty, which can then become a national security issue. In that sense, the discourse will emphasize the critical role of the resource for the survival of states, humans, etc. This will result in the attachment of the resource to a set of larger values, benefits, and expected costs. The other one is tactical securitization that occurs when issues considered to be low politics are linked with the high politics of national survival. Embedding a lower priority resource in a wider political and existential setting is designed to capture policy-makers' attention and to allow actors to gain an edge in the agenda-setting process. Our case seems to conform to the latter type of securitization as a social contract tactic since (as seen in Figure 1) most of the securitized statements were lacking a clear dominant threat that could have justified a genuine physical trigger for such rhetoric. While securitization varies between issues, the two competition indexes, which were built to reflect the competition level between securities, witnessed for the most part low to mild rates.

Figure 2 also reveals that only in the last several years this competition seems to be intensified mostly at political venues. This may be a result on the recent offshore Israeli gas discoveries that may have motivated players to become more rhetorically aggressive. Yet, this finding requires further study. In the cases where competition was evident, the rhetoric of the competition is explicit and blunt. Often this competition was presented as a policy dilemma for the need to prioritize between competing securities rather than as a clash. For example, the Israeli Society for Nature protection argues:

for the need to find the right balance between the energy needs of Israel and its ecological needs. The ecological needs are both less important than other needs as they are the environmental services that are essential for our existence. (Sagi, 2011)

The research of Rogers-Hayden, Hatton, and Lorenzoni (2011), which studied how issues are framed while promoting different energy solutions in the UK, demonstrates the role of hegemonic discourses versus counter-hegemonic discourses. In the Israeli planning context "traditional security" is often considered to be the hegemonic discourse (Perez \& Rozenblum, 2007). Hence, not surprisingly, in this study many of the securitized statements included a reference to traditional security issues as an existential need of Israel and its control over land. Alongside this "traditional security" stands a second hegemonic discourse, which can be called the "energy security" discourse. This energy discourse was the most securitized and explicitly expressed amongst the remaining competing uses. Despite the numerous definitions for energy security that exist in the literature (Kruyt, Van Vuuren, de Vries, \& Groenenberg, 2009), in this case study energy security mostly implied reliable energy supply and 
energy independency, a concept that is often deployed to address issues of national sovereignty (see Figure 1). Hence, energy security seems to complement the traditional security issue rather than compete against it, which may contribute to the low levels of the competing security indexes. Framing "energy security" as part of "traditional security" is well understood given the Israeli geo-political context: as an energy island with scarce energy resources coupled with a history of energy embargos (Shaffer, 2011).

In conjunction with the two identified hegemonic discourses, the study identified two alternative counter-discourses that competed over land with the energy and traditional securities. The first discourse concerns the protection of agricultural lands, which was framed on occasion as a "food security" issue. The second discourse pertains to "ecological security" framed for the purpose of protecting pristine nature. Yet, their uses with securitization framing remains marginal and they were usually discussed in an implicit manner by the agricultural and environmental sectors, respectively (see Tables 2 and 4). Their marginalization expresses their status as unsaid discourses, discourses that cannot be spoken or accepted publicly or politically. The disallowance of ecological and food security discourses thus also explains the low levels of the two competition indexes, as the Israeli political context prohibits the challenging of traditional security.

\section{Conclusions}

The Copenhagen School has established an approach that sees securitization as a socially constructed act in which an actor exposes a threat to a referent object and wishes to promote a solution while displaying it in a securitized manner. As such, there are scholars who see the social and discursive process of securitization as part of a framing approach whereby actors frame issues in certain ways for the purpose of affecting policy-makers or the public in agenda-setting. While there are several studies that document the use of existential and securitized language pertaining to several resources (e.g. water, energy, food), these studies have typically underplayed the inextricable interdependence between natural resources; this implies that securing resources for one use can create insecurities for other competing uses. Hence, the aim of this study has been not solely to identify the use of varying securitized discourses related to land use, but to spearhead the identification of the evolution of competing security discourses in decision-making processes over the appropriation of space.

The results of the research, which indicate that many securitized statements do not include concrete threats to referent objects, strengthen the perception that securitization is a socially constructed process aimed at prioritizing certain uses over alternative ones. Yet, cases where a concrete threat to a referent object was identified revealed that the meaning of what was securitized differs across players, sectors, and uses. This has demonstrated that resource-based securitization develops through negotiations between discourses and material realities over time, and can hold multiple meanings, often as a function of the securitizing sector and actor.

The ability to use and abuse securitization language for the purpose of promoting conflicting agendas is a result of the ambiguity of the concept's definition. In the 
USA, for example, the loose use of terms like "energy security" and "energy independency" encourages the negotiation of discourse in the public and decisionmaking spheres (Littlefield, 2013). Indeed, the instrumental use of energy security was already documented in several studies (e.g. Bang, 2010; Rogers-Hayden et al., 2011), whereas attention-raising concepts (like energy security and climate change) have been seen to be coupled together for the purpose of promoting certain policies like greenhouse gas reductions. Yet, this work has shown that varying frames of "energy security" can be deployed in contradiction-and in opposition-to one another while seeking to achieve competing policies.

Tim Forsyth has stated, "assessments of frames should not just be limited to those that are labelled as important at present, but also seek to consider alternative framings that may not currently be considered important in political debates" (2003, p. 1). An aim of this study has been to interrogate how, where, and by whom "securitization" framing is constructed. The results, in turn, inform how these framings influence decision-making. Interpretation of what entails "security" implies that stakeholders collided and conflicted in their interpretation of what land use should be securitized. In fact, this research found that debating land use policy often became increasingly disorderly as stakeholders challenged the importance and even the legitimacy of other securitized land uses. Harnessing vulnerabilities for the framing of land uses as a security issue was found to also legitimize labeling these uses as national polices that should be prioritized over other policies.

In the Israeli volatile security context, one may question the generality of these results to other cases, characterized by a more amicable physical and social context where other uses may be less adjudicated by the logic of securitization. Yet, it seems that even in this hyper case study (where the traditional security establishment often has the upper hand) other competing uses were able to challenge the dominant hegemony by suggesting alternative interpretations to traditional security, given that one would expect a similar securitization contest in less contentious cases where challenging the traditional security establishment may be easier. This requires the need to empirically examine if parties in different settings will converge around securitization as a framing mode, or would develop framing contest around a different theme, one that is more suitable for their context. Early evidence already points toward the applicability of securitization as a framing mode to other cases like the USA (Floyd, 2010) or to the work of global institutions like the UN Commission for Sustainable Development (Fischhendler \& Katz, 2012).

This case study investigation provides added value to ongoing interrogations regarding how interactions between discourses and materiality shape decisionmaking across our shared social, cultural, and political body. More specifically, this work helps to illustrate how framing practices have constructed securitized discourses in the context of solar energy promotion in the Israeli Negev desert. In this way, our work also traces how power is situated in professional and disciplinary practices, making actors both the object of discipline and the instruments of its exercise (Foucault, 1984). Moving forward, further work examining how power saturates 
"securitization framing" in varied social, political, economic, and institutional conditions is warranted.

\section{References}

Anderson, A. (1997). Media, culture and the environment. London: Routledge.

Bahgat, G. (2008). Energy and the Arab-Israeli conflict. Middle Eastern Studies, 44, 937-944. doi:10.1080/00263200802426195

Balzacq, T. (2005). The three faces of securitization: Political agency, audience and context. European Journal of International Relations, 11, 171-201. doi:10.1177/1354066105052960

Bang, G. (2010). Energy security and climate change concerns: Triggers for energy policy change in the United States? Energy Policy, 38, 1645-1653. doi:10.1016/j.enpol.2009.01.045

Brown, S. P. A., \& Huntington, H. G. (2008). Energy security and climate change protection: Complementary or tradeoff? Energy Policy, 36, 3510-3513. doi:10.1016/j.enpol.2008.05.027

Buzan, B. (1997). Rethinking security after the cold war. Cooperation and Conflict, 32(1), 5-28. doi:10.1177/0010836797032001001

Buzan, B., \& Wæver, O. (1997). Slippery? contradictory? sociologically untenable? The Copenhagen school replies. Review of International Studies, 23, 241-250. doi:10.1017/S0260210597002416

Buzan, B., Waever, O., \& De Wilde, J. (1998). Security: A new framework for analysis. London: Lynne Rienner.

Carvalho, A., \& Peterson, T. R. (Eds.). (2012). Climate change politics: Communication and public engagement. London: Cambria Press.

Central Bureau of Statistics. (2012). Statistical abstract of Israel 2012: Population density per Sq. Km. of land, by district and sub-district. Retrieved from http://www.cbs.gov.il/reader

Chiabrando, R., Fabrizio, E., \& Garnero, G. (2009). The territorial and landscape impacts of photovoltaic systems: Definition of impacts and assessment of the glare risk. Renewable and Sustainable Energy Reviews, 13, 2441-2451. doi:10.1016/j.rser.2009.06.008

Chong, D., \& Druckman, J. N. (2007). A theory of framing and opinion formation in competitive elite environments. Journal of Communication, 57(1), 99-118.

Ciută, F. (2010). Conceptual notes on energy security: Total or banal security? Security Dialogue, 41 (2), 123-144. doi:10.1177/0967010610361596

Cox, R. (2006). Environmental communication in the public sphere. Los Angeles, CA: Sage.

Cox, R. (2010). Beyond frames: Recovering the strategic in climate communication. Environmental Communication, 4(1), 122-133.

Davies, S., \& Selin, C. (2012). Energy futures: Five dilemmas of the practice of anticipatory governance. Environmental Communication, 6(1), 119-136.

Dearing, W., \& Rogers, E. (1996). Communication concepts 6: Agenda-setting. Newbury Park, CA: Sage.

Deshe Institute. (2012). Retrieved from http://www.deshe.org.il/

Deudney, D. (1990). The case against linking environmental degradation and national security. Journal of International Studies, 19, 461-476.

Deudney, D. (1991). Environment and security: Muddled thinking. Bulletin of the Atomic Scientists, $47(3), 22-28$.

Dibden, J., Gibbs, D., \& Cocklin, C. (2013). Framing GM crops as a food security solution. Journal of Rural Studies, 29, 59-70.

Dryzek, J. S. (1997). The politics of the earth: Environmental discourses. New York: Oxford University Press.

Dupraz, C., Marrou, H., Talbot, G., Dufour, L., Nogier, A., \& Ferard, Y. (2011). Combining solar photovoltaic panels and food crops for optimizing land use: Toward new agrivoltaic scheme. Renewable Energy, 36, 2725-2732. doi:10.1016/j.renene.2011.03.005 
Erge, T., Hoffmann, V. U., \& Kiefer, K. (2001). The German experience with grid-connected PVsystems. Solar Energy, 70, 479-487. doi:10.1016/S0038-092X(00)00143-2

Fischhendler, I., \& Katz, D. (2012). The use of "security" jargon in sustainable development discourse: Evidence from UN commission on sustainable development. International Environmental Agreements: Politics, Law and Economics, 13, 321-342. doi:10.1007/s10784012-9192-z

Floyd, R. (2007). Toward a consequentialist evaluation of security: Bring together the Copenhagen and the Welsh Schools of security studies. Review of International Studies, 33, 327-350. doi:10.1017/S026021050700753X

Floyd, R. (2010). Security and the environment: Securitization theory and US environmental security policy. Cambridge: Cambridge University Press.

Floyd, R. (2012). Climate change, environmental security studies and the mortality of climate security. Retrieved from http://www.e-ir.info/

Forsyth, T. (2003). Critical political ecology: The politics of environmental science. London: Routledge.

Foucault, M. (1984). Space, knowledge and power. In P. Rabinow (Ed.), The Foucault reader (pp. 239-256). New York, NY: Pantheon Books.

Gamson, W. A., \& Modigliani, A. (1989). Media discourse and public opinion on nuclear power: A constructionist approach. American Journal of Sociology, 95(1), 1-37. doi:10.1086/229213

Garcia, A., Alzate, J., \& Barrera, J. (2012). Regulatory design and incentives for renewable energy. Journal of Regulatory Economics, 41, 315-336. doi:10.1007/s11149-012-9188-1

Gerlak, A. K. (2013). Unpacking discourse around the human right to water. Paper presented at the 54th Convention of the International Studies Association, San Francisco, 3-6 April 2013.

Government of Israel. (2002). Decision number 2664: Electricity generation policy - renewable energy (Heb).

Government of Israel. (2007). Decision number 2178: Barriers removal in the energy sector (Heb), 12.8.2007.

Government of Israel. (2008). Decision number 2935: Plan for encouraging the use with clean energy (Heb), 13.1.2008.

Government of Israel. (2009). Decision number 4450: Setting objective and tools for promoting renewable energies especially in the Negev and the Arava (Heb), 29.1.2009.

Hajer, M. (1993). Discourse coalitions and the institutionalization of practice: The case of acid rain in Britain. In F. Fisher \& J. Forester (Eds.), The argumentative turn in policy analysis and policymaking (pp. 43-76). Durham, NC: Duke University Press.

Hall, S. (1997). Representation: Cultural representation and signifying practices. Thousand Oaks, CA: Sage.

Hanjra, M. A., \& Qureshi, M. E. (2010). Global water crisis and the future food security in an era of climate change. Food Policy, 35, 365-377. doi:10.1016/j.foodpol.2010.05.006

Hansen, A. (1991). The media and the social construction of the environment. Media, Culture of Society, 13, 443-458.

Harvey, D. (1990). Between space and time: Reflections on the geographical imagination. Annals of the Association of American Geographers, 80, 418-434. doi:10.1111/j.1467-8306.1990. tb00305.x

Hilgartner, S., \& Bosk, C. L. (1988). The rise and fall of social problems: A public arenas model. American Journal of Sociology, 94(1), 53-78. doi:10.1086/228951

Homer-Dixon, T. F. (1991). On the threshold: Environmental change as causes of acute conflict. International Security, 16(2), 76-116. doi:10.2307/2539061

Inouye, D. W. (2008). Biodiversity and ecological security. In D. Pireages \& K. Cousins (Eds.), From resource scarcity to ecological security (pp. 203-215). New Delhi: Academic Foundation.

Israel Electric Corp. (2012). Statistical report for year 2011 (Heb). Haifa: Author.

Israel Nature and Parks Authority. (2012). Retrieved from http://www.parks.org.il 
Jacobsson, S., \& Bergek, A. (2004). Transforming the energy sector: The evolution of technological system in renewable energy technology. Industrial and Corporate Change, 13, 815-849. doi:10.1093/icc/dth032

Kauffman, C. M. (2013). Framing strategies in transnational campaigns for watershed management reform. Paper presented at the 54th Convention of the International Studies Association, San Francisco, April 3-6, 2013.

Kruyt, B., Van Vuuren, D., de Vries, H., \& Groenenberg, B. (2009). Indicators for energy security. Energy Policy, 37, 2166-2181. doi:10.1016/j.enpol.2009.02.006

Lakoff, G. (2010). Why it matters how we frame the environment. Environmental Communication, $4(1), 70-81$.

Levy, M. A. (1995). Is the environment a national security issue? International Security, 20(2), 3562. doi: $10.2307 / 2539228$

Littlefield, S. R. (2013). Security, independence, and sustainability: Imprecise language and the manipulation of energy policy in the United States. Energy Policy, 52, 779-788. doi:10.1016/j. enpol.2012.10.040

Maxwell, S. (1996). Food security: A post-modern perspective. Food Policy, 21, 155-170. doi:10.1016/0306-9192(95)00074-7

Ministry of Agriculture \& Rural Development. (2007). Law for capital investments encouragement in agriculture-national preference areas setting. Jerusalem: Author.

Ministry of Environmental Protection. (2011). OECD environmental performance review of Israel. (Heb, T. Shevah, Transl. from English). Jerusalem: Author.

Oliver, M., \& Jackson, T. (2001). Energy and economic evaluation of building-integrated photovoltaics. Energy, 26, 431-439. doi:10.1016/S0360-5442(01)00009-3

Pelling, M., \& Dill, K. (2006). Natural disasters as catalysts of political action. Chatham House. ISP/ NSC Briefing Paper 06/01, pp. 4-6.

Perez, O., \& Rozenblum, E. (2007). Chronicle of planning hegemonic: The status of the security constitution in the planning processes in the perspective of the environmental struggle for the saving of Atlit Shore (2001-2003) (Heb). Law Research, 23, 371-431.

Risbey, J. S. (2008). The new climate discourse: Alarmist or alarming? Global Environmental Change, 18(1), 26-37. doi:10.1016/j.gloenvcha.2007.06.003

Rogers-Hayden, T., Hatton, F., \& Lorenzoni, I. (2011). 'Energy security' and 'climate change': Constructing UK energy discursive realities. Global Environmental Change, 21, 143-142. doi:10.1016/j.gloenvcha.2010.09.003

Sabatier, P. A. (2011). The advocacy coalition framework: Revisions and relevance for Europe. Journal of European Public Policy, 5(1), 98-130. doi:10.1080/13501768880000051

Sagi, Y. (2011). Yoav Sagi, representative of the Israeli society for Nature Protection. From the protocol of the Environmental Protection and Interior Committee of the Knesset, 7/11/11, Jerusalem.

Shaffer, B. (2011). Israel-new natural gas producer in the Mediterranean. Energy Policy, 39, 53795387. doi:10.1016/j.enpol.2011.05.026

Stripple, J. (2002). Climate change as a security issue. In E. A. Page \& M. Redclift (Eds.), Human security and the environment: International comparisons (pp. 105-127). Glos: Edward Elgar.

The State Comptroller. (2011). Annual Report 61 for the Year 2010 (Heb). Jerusalem: Author.

Timilsina, G., Kurdgelashvili, L., \& Narbel, P. (2012). Solar energy: Markets, economics and policies. Renewable \& Sustainable Energy Reviews, 16, 449-465. doi:10.1016/j.rser.2011.08.009

Timmons, J. F. (1956). Theoretical considerations of water allocation among competing uses and users. Journal of Farm Economics, 38, 1244-1258. doi:10.2307/1234539

Trombetta, M. J. (2008). Environmental security and climate change: Analysing the discourse. Cambridge Review of International Affairs, 21, 585-602. doi:10.1080/09557570802452920

United Nations. (1994). Human development report: New dimensions of human security. New York, NY: UNDP. Retrieved from http://hdr.undp.org/en/media/hdr_1994_en.pdf 
Van Dijk, T. A. (1988). News as discourse. Hillsdale, NJ: Laurence Erlbaum.

Wæver, O. (1995). Identity, integration and security: Solving the sovereignty puzzle in E.U. studies. Journal of International Affairs, 48, 389-431.

Yang, H., Zhou, Y., \& Liu. J. (2009). Land and water requirements of biofuel and implications for food supply and environment in China. Energy Policy, 37, 1876-1885.

Yergin, D. (2006). Ensuring energy security. Foreign Affairs, 85(2), 69-82.

Zeitoun, M. (2011). The global web of national water security. Global Policy, 2, 286-296. 